\title{
PENERAPAN MODEL PEMBELAJARAN PROBLEM BASED LEARNING (PBL) DENGAN PENDEKATAN SAINTIFIK UNTUK MENINGKATKAN HASIL BELAJAR IPS
}

\author{
I Ketut Sudasma \\ SMP Negeri 1 Dawan \\ Email: suryadasma@gmail.com
}

\begin{abstract}
ABSTRAK
Pelaksanaan penelitian ini bertujuan untuk mengetahui peningkatan hasil belajar siswa setelah diterapkan model pembelajaran Problem Based Learning (PBL) dengan pendekatan saintifik dalam proses pembelajaran. Permasalahan awal yang terjadi adalah belum maksimalnya proses pembelajaran yang dilakukan guru dalam meningkatkan hasil belajar siswa akibat penerapan model pembelajaran Problem Based Learning (PBL) yang masih belum maksimal. Setelah data dikumpulkan menggunakan alat berupa tes hasil belajar siswa dari rata-rata awal 68,16 dengan prosentase ketuntasan belajar sebesar 32,00\% naik menjadi 73,72 dengan prosentase ketuntasan belajar sebesar $76,00 \%$ pada siklus I dan naik menjadi 80,72 pada persentase ketuntasan belajar $100,00 \%$ pada siklus II. Dengan perolehan data tersebut dapat dipastikan bahwa penerapan model pembelajaran Problem Based Learning (PBL) dengan pendekatan saintifik dapat meningkatkan hasil belajar IPS siswa sehingga hipotesis yang diajukan dapat diterima.
\end{abstract}

Kata kunci : model pembelajaran Problem Based Learning (PBL), pendekatan saintifik, hasil belajar

\section{ABSTRACT}

The purpose of this research is to find out the improvement of student learning outcomes after applying the Problem Based Learning (PBL) learning model with a scientific approach in the learning process. The initial problem that occurs is that the learning process undertaken by the teacher is not yet optimal in improving student learning outcomes due to the application of the Problem Based Learning (PBL) learning model which is still not optimal. After the data were collected using a tool in the form of a test of student learning outcomes from the initial average of 68.16 with the percentage of mastery learning by $32.00 \%$ rose to 73.72 with the percentage of mastery learning by $76.00 \%$ in the first cycle and rose to 80.72 the percentage of mastery learning $100.00 \%$ in cycle II. With the acquisition of these data it can be ensured that the application of the Problem Based Learning (PBL) learning model with a scientific approach can improve student social learning outcomes so that the proposed hypothesis can be accepted.

Keywords: Problem Based Learning (PBL) Learning Model, Scientific Approach, Learning Outcomes

\section{PENDAHULUAN}

Dalam era globalisasi dan pasar bebas manusia dihadapkan pada tantangan yang berat yang ditandai dengan adanya perubahan yang tidak menentu. Dalam menghadapi tantangan tersebut dibutuhkan kekuatan diri dari masing-masing warga negara dan kekuatan kohesi sosial dalam bidang politik, ekonomi, dan budaya. Kekuatan diri yang diharapkan adalah menjadi manusia yang beriman dan bertaqwa kepada Tuhan Yang Maha Esa, berakhlak mulia, sehat, berilmu, cakap, kreatif, mandiri, demokratis, dan bertanggung jawab (Depdiknas, 2003). diperlukan sumber daya manusia yang mampu menjawab tantangan dan akan mengantarkan bagaimana suatu bangsa dapat berkontribusi secara internasional. 
Terkait dengan permasalahan tersebut, dunia pendidikan mendapat sorotan yang sangat tajam berkaitan dengan tuntutan untuk menghasilakan sumber daya manusia yang mampu "hidup" di abad ke-21. Pendidikan sebagai sumber daya insani sepatutnyalah mendapatkan perhatian secara terus menerus dalam upaya peningkatan mutunya. Peningkatan mutu pendidikan berarti pula peningkatan kualitas sumber daya manusia.

Dalam Undang-Undang No. 20 Tahun 2003 tentang Sistem Pendidikan Nasional pada Pasal 3 disebutkan bahwa pendidikan nasional berfungsi mengembangkan kemampuan dan membentuk karakter serta peradaban bangsa yang bermartabat dalam rangka mencerdaskan kehidupan bangsa. Pendidikan nasional bertujuan untuk mengembangkan potensi peserta didik agar menjadi manusia yang beriman dan bertakwa kepada Tuhan Yang Maha Esa, berakhlak mulia, sehat, berilmu, cakap, kreatif, mandiri, dan menjadi warga negara yang demokratis serta bertanggung jawab. Untuk mencapai tujuan pendidikan nasional tersebut dan mewujudkan pendidikan sebagai proses pencerdasan kehidupan bangsa dalam arti utuh dan luas, maka Kurikulum 2013 dirancang secara utuh, tidak hanya aspek kognitif dan psikomotor tetapi juga sikap spiritual dan sikap sosial. Disamping itu, kurikulum 2013 menuntut pembelajaran IPS (Ilmu Pengetahuan Sosial) yang disampaikan secara terpadu. Dengan pembelajaran secara terpadu, diharapkan pembelajaran IPS lebih bermakna bagi peserta didik dalam konteks pembelajaran sehari-hari. Peserta didik akan memperoleh pemahaman yang lebih luas dan utuh. Mata pelajaran IPS mengkaji berbagai aspek kehidupan masyarakat secara terpadu, karena kehidupan masyarakat sebenarnya merupakan sebuah system dan totalitas dari berbagai aspek. Kehidupan masyarakat bersifat multidimensional, sehingga pembelajaran IPS yang dilaksanakan secara terpadu diharapkan mampu mengantarkan dan mengembangkan kompetensi peserta didik kearah kehidupan masyarakat dengan baik dan fungsional, memiliki kepekaan sosial dan mampu berpartisipasi dalam mengatasi masalah-masalah sosial yang terjadi.

Berdasarkan Peraturan Menteri Pendidikan dan Kebudayaan Nomor 68 Tahun 2013 Tentang Kerangka Dasar dan Struktur Kurikulum Sekolah Menengah Pertama/Madrasah Tsanawiyah, Kurikulum 2013 dikembangkan dengan penyempurnaan sejumlah pola pikir yang dikembangkan pada kurikulum sebelumnya. Salah satu diantaranya adalah pola pembelajaran pasif menjadi pembelajaran aktif-mencari. Pola pikir yang berubah tersebut, menuntut juga perubahan dalam pendekatan pembelajarannya. Pendekatan Scientific atau ilmiah dipilih sebagai pendekatan dalam pembelajaran dalam kurikulum 2013. Peserta didik secara aktif membangun pengetahuannya sendiri melalui aktivitas ilmiah yaitu mengamati, menanya, mengumpulkan informasi, menalar/ mengasosiasi, mengkomunikasikan.

Dalam implementasi kurikulum 2013 yang berpendekatan saintifik, pembelajaran IPS mau tidak mau harus dilaksanakan melalui metode yang dapat mengantarkan siswa untuk menyadari bahwa IPS atau peristiwa itu tidak ada di sekitarnya dan banyak masalah yang berkaitan dengan kejadian 
dilingkungannya yang memerlukan pemecahan.

Biasanya pembelajaran IPS di sekolah-sekolah menengah pertama masih lebih dominan dilaksanakan dengan cara penyampaian penjelasan-penjelasan teoritik dan informasi yang hanya datang dari satu arah yakni dari guru. Dalam hal ini seolah-olah guru merupakan satusatunya sumber belajar, komunikasi hanya satu arah, siswa kurang terlibat dalam pembelajaran. Siswa hanya sebagai pendengar dan pembelajaran berpusat pada guru (teacher centred, hal semacam inilah menjadikan pembelajaran kurang bermakna bagi siswa. Pembelajaran IPS melalui penerapan model Problem Based Learning (PBL) berpendekatan Saintifik dapat membangun masyarakat belajar di dalam kelas.

Penerapan model Problem Based Learning (PBL) berpendekatan Saintifik dapat melatih siswa untuk mengembangkan potensi dirinya untuk memperoleh sejumlah pengalaman belajar, sehingga siswa nantinya mampu memecahkan persoalan-persoalan hidupnya. Melalui pembelajaran dengan model Problem Based Learning (PBL) berpendekatan Saintifik, siswa lebih dapat diberdayakan dan mereka terdorong untuk mau dan mampu berbuat untuk memperkaya pengalaman belajarnya dengan cara meningkatkan interaksi dengan lingkungan fisik dan sosialnya, sehingga mampu membangun pemahaman dan pengetahuannya terhadap dunia disekitarnya. Melalui interaksi dengan lingkungannya mereka memperoleh hasil karena dapat membangun pengetahuan dan kepercayaan diri, dan begitu pula mereka saling dapat berinteraksi sosial dengan individu lain yang berbeda satu sama lain baik ras, agama, jenis kelamin, dan tentunya kemampuan akademik serta bisa saling menghormati kelebihan dan kekurangan masing-masing.

Pembelajaran IPS dengan memerapkan model pembelajaran Problem Based Learning (PBL) berpendekatan Saintifik dapat memotivasi siswa lebih kreatif, lebih produktif, dan mampu melatih keterampilan problem solving siswa. IPS yang selama ini dianggap sebagai momok oleh sebagian besar siswa, dengan pendekatan dan metode pembelajaran yang lebih banyak menuntut pelibatan siswa diharapkan IPS menjadi lebih disenangi dan siswa-siswa menjadi lebih tertarik dalam belajar. Melalui pendekatan pembelajaran berbasis masalah, siswa mencarikan solusi melalui kegiatan kooperatif, dimana setiap kelompok terdiri atas anggota yang heterogin, baik kemampuan akademik, jenis kelamin dan juga status sosial. Kelompok seperti ini, dapat mewujudkan adanya interaksi dan komunikasi multi arah dan kerja sama anatar anggota benarbenar dapat terwujud. Hasil belajar yang diperoleh setiap anggota kelompok dalam satu kelompok tidak jauh berbeda. Mereka dapat mencapai tujuan pembelajaran secara bersama-sama, karena keberhasilan kelompok menjadi tanggung jawab mereka bersama.

Berdasarkan uraian diatas dapat dirumuskan permasalahan sebagai berikut : Apakah penerapan model Pembelajaran Problem Based Learning (PBL) dengan pendekatan saintifik dapat meningkatkan hasil belajar IPS siswa kelas IX A SMP Negeri 1 Dawan semester ganjil tahun pelajaran 2016/2017? Adapun tujuan dari penelitian tindakan ini adalah : Untuk mengetahui seberapa besar penerapan model Pembelajaran Problem Based Learning (PBL) dengan pendekatan 
Saintifik dapat meningkatkan hasil belajar IPS siswa kelas IX A SMP Negeri 1 Dawan semester ganjil tahun pelajaran 2016/2017. Dari penelitian ini diharapkan manfaat yang dapat diperoleh adalah : 1) Guru yang terlibat langsung dalam kegiatan ini akan memiliki peningkatan pengetahuan tentang berbagai faktor yang berhubungan dengan model Pembelajaran Problem Based Learning (PBL) dengan pendekatan Saintifik. 2) Guru yang terlibat dalam penelitian ini memiliki alternatif dalam pelaksanaan pembelajaran IPS agar dapat memperbaiki mutu proses pembelajaran. 3) Dengan mempelajari dan melaksanakan model pembelajaran problem based learning (PBL) dengan pendekatan saintifik, diharapkan persepsi guru tentang belajar kelompok akan berubah. 4) Bagi siswa, khususnya siswa kelas IX A semester ganjil tahun 2016/2017 dapat meningkatkan keterlibatannya dalam kegiatan pembelajaran sehingga pembelajaran menjadi bermakna. 5) Sekolah yang dijadikan lokasi penelitian dapat menjadi sekolah awal dalam pengembangan pendekatan dan metode-metode pembelajaran inovatif.

Pembelajaran pada Kurikulum 2013 menggunakan pendekatan saintifik atau pendekatan berbasis proses keilmuan. Pendekatan saintifik dapat menggunakan beberapa strategi seperti pembelajaran kontektual. Model pembelajaran merupakan suatu bentuk pembelajaran yang memiliki nama, ciri, sintak, pengaturan, dan budaya misalnya discovery learning, project based learning, problem based learning (PBL), inquiry learning (Permendikbud No 103 Tahun 2014). Model pembelajaran PBL sepertinya merupakan hal baru dalam pembelajaran IPS tetapi tidak demikian halnya karena dalam pembelajaran IPS pengajuan masalah selalu dimunculkan hampir disetiap pembelajaran, hanya saja permasalahan yang disampaikan mungkin masih belum dirumuskan dengan sebaikbaiknya.

Model pembelajaran PBL belakangan banyak dikembangkan di Jepang terutama masalah-masalah berbentuk open ended. Pendekatan ini didasarkan atas penelitian shimada di bidang matematika (Sudiarta, 2005). Pendekatan ini akhirnya berkembang pesat sampai di Amerika dan Eropa yang selanjutnya dikenal secara umum dengan istilah "(open Ended Problem Solving)" secara eksplisit pendekatan pembelajaran berdasarkan masalah di Indonesia belum begitu disosialisasikan penggunaannya. IPS tidak terlepas dari kehidupan dunia nyata dan hampir senantiasa berkaitan dan berhubungan dengan manusia. Dalam hal ini terkadang ada yang dapat dengan segera menyadari ada pula yang kurang menyadari bahwa IPS ada di sekitarnya dan telah mereka manfaatkan.

Permasalahan yang berkaitan dengan IPS meliputi permasalahan sederhana yang hanya membutuhkan pemecahan sederhana pula dan dapat dengan mudah diselesaikan, dan ada pula permasalahan yang kompleks dan pemecahannya tidak mudah ditebak jawabannya dan bahkan harus dipecahkan dari berbagai sisi khusus untuk masalahmasalah yang kompleks, sering menimbulkan solusi dengan penafsiran yang beragam dan membutuhan nalar yang lebih tinggi. Untuk memecahkan masalahmasalah IPS baik ynag sederhana maupun kompleks lebih mudah melalui kegiatan pembeljaran yang mencerminkan aktivitas siswa lebih optimal. 
Pembelajaran berdasarkan masalah, mampu mendorong siswa untuk berpikir lebih kritis, terbuka dan bekerja sama dan berkompeten dalam pemecahan masalah dan dalam berkomunikasi secara logis dan argumentatif. Ini menjadi alasan mengapa pembelajaran IPS dengan berdasarkan masalah perlu dikembangkan. Didasati bahwa dalam pembelajaran IPS istilah pendekatan pembelajaran ini merupakan hal baru, berbeda dengan di Matematika yang perkembangannya begitu pesat terhadap penggunaan pendekatan pembelajaran berdasarkan masalah dengan sebutan open ended problem.

Pola pikir yang berubah tersebut, menuntut juga perubahan dalam pendekatan pembelajarannya. Pendekatan Scientific atau ilmiah dipilih sebagai pendekatan dalam pembelajaran dalam kurikulum 2013. Peserta didik secara aktif membangun pengetahuannya sendiri melalui aktivitas ilmiah yaitu 1) Mengamati. Kegiatan mengamati dapat dilakukan dalam dua cara yaitu pengamatan langsung di lapangan atau di luar sekolah terhadap objek yang dipelajari dan pengamatan secara tidak langsung dengan memperhatikan data, gambar, foto, tayangan film tentang objek dipelajari. Pengamatan juga dapat dilakukan dengan meminta peserta didik mengingat kembali objek atau peristiwa yang pernah mereka lihat atau alami. Kegiatan mengamati dalam pembelajaran, termasuk pembelajaran IPS, dilakukan dengan menempuh langkah-langkah berikut ini. a) Menentukan objek apa yang akan diobservasi. b) Membuat pedoman observasi sesuai dengan lingkup objek yang akan diobservasi. c) Menentukan secara jelas data apa yang perlu diobservasi, baik primer maupun sekunder. d) Menentukan di mana tempat objek yang akan diobservasi. e) Menentukan secara jelas bagaimana observasi akan dilakukan untuk mengumpulkan data agar berjalan mudah dan lancer. f) Menentukan cara dan melakukan pencatatan atas hasil observasi, seperti menggunakan buku catatan, kamera, tape recorder, video perekam, dan alat-alat tulis lainnya. Praktik observasi dalam pembelajaran hanya akan efektif jika peserta didik dan guru melengkapi diri dengan dengan alat-alat pencatatan dan alat-alat lain, seperti: (1) tape recorder, untuk merekam pembicaraan; (1) kamera, untuk merekam objek atau kegiatan secara visual; (2) film atau video, untuk merekam kegiatan objek atau secara audio-visual; dan (3) alat-alat lain sesuai dengan keperluan. 2. Menanya. Setelah proses observasi selesai, maka aktivitas berikutnya adalah peserta didik mengajukan sejumlah pertanyaan berdasarkan hasil pengamatannya. Jadi, aktivitas menanya bukan aktivitas yang dilakukan oleh guru, melainkan oleh peserta didik berdasarkan hasil pegamatan yang telah mereka lakukan. Aktivitas menanya merupakan keterampilan yag perlu dilatih. Kelemahan pendidikan selama ini salah satunya karena peserta didik tidak biasa mengemukakan pertanyaan sebagai hasil dari proses berfikir yang mereka lakukan. Keterampilan menyusun pertanyaan ini sangat penting untuk melatih daya kritisnya. 3. Mengumpulkan informasi. Setelah proses menanya, aktivitas berikutnya adalah mengumpulkan data dan informasi dari berbagai sumber. Data dan informasi dapat diperoleh secara langsung dari lapangan (data primer) maupun dari berbagai bahan bacaan (data sekunder). Hasil pengumpulan data tersebut kemudian menjadi bahan bagi peserta didik untuk melakukan penalaran antara 
satu data atau fakta dengan data atau fakta lainnya untuk dikaji ada tidaknya asosiasi diantara keduanya. Penalaran adalah proses berfikir yang logis dan sistematis atas fakta-kata empiris yang dapat diobservasi untuk memperoleh simpulan berupa pengetahuan. Penalaran dimaksud merupakan penalaran ilmiah. Istilah menalar di sini merupakan padanan dari associating, bukan merupakan terjemanan dari reasoning, meski istilah ini juga bermakna menalar atau penalaran. Karena itu, istilah aktivitas menalar dalam konteks pembelajaran pada Kurikulum 2013 dengan pendekatan ilmiah banyak merujuk pada teori belajar asosiasi atau pembelajaran asosiatif. Istilah asosiasi dalam pembelajaran merujuk pada kemampuan mengelompokkan beragam ide dan mengasosiasikan beragam peristiwa untuk kemudian memasukannya menjadi penggalan memori. 4. Menalar/ Mengasosiasi. Menalar/mengasosiasi dalam pembelajaran IPS agak berbeda dengan IPA. Kegiatan menalar/ mengasosiasi dalam IPA banyak menggunakan bahan dan alat. Dalam pembelajarn IPS pengertian mencoba disini dapat diartikan secara sempit seperti menunjukkan dan dapat diartikan secara luas yaitu membuktikan. Hasil dari aktivitas mencoba adalah munculnya kesimpulan. Pengertian menyimpulkan disini mengandung dua pengertian, yaitu mengaitkan konsep dalam IPS itu sendiri dan mengaitkan konsep yang diperoleh dengan dunia nyata. Hasil praktek yang diperoleh oleh peserta didik digunakan untuk aplikasi dalam dunia nyata dikaitkan dengan pengetahuan. 5. Mengomunikasikan. Mengkomunikasikan dalam konteks pendekatan pembelajaran scientific dapat berupa penyampaian hasil atau temuan kepada pihak lain. Keterampilan menyajikan atau mengkomunikasikan hasil temuan atau kesimpulan sangat penting dilatih sebagai bagian penting dalam proses pembelajaran. Dengan kemampuan tersebut, peserta didik dapat mengkomunikasikan secara jelas, santun, dan beretika.

(Dimyati \& Moerdjiono, 1994) bahwa "hasil belajar merupakan hasil dari suatu interaksi tindak mengajar atau tindak belajar". Sedangkan (Soeharto, 1984) menyatakan bahwa "belajar ditandai oleh ciri-ciri yaitu: (a). Disengaja dan bertujuan, (b). Tahan lama, (c). Bukan karena kebetulan, (d). Bukan karena kematangan dan pertumbuhan". Demikian pula dalam kamus umum Bahasa Indonesia disebutkan bahwa "hasil belajar merupakan sesuatu yang diadakan,dibuat,dijadikan oleh suatu usaha atau dapat juga berarti pendapat atau perolehan, buah (Poerwadarminta, 1996). (Gagne RM, 1988) mengatakan bahwa ada lima kemampuan hasil belajar yaitu : 1) keterampilan-keterampilan intelektual, karena keterampilan itu merupakan penampilan yang ditunjukkan oleh siswa tentang operasi intelektual yang dapat dilakukannya, 2) penggunaan strategi kognitif, karena siswa perlu menunjukkan penampilan yang baru, 3) berhubungan dengan sikap-sikap yang dapat ditunjukkan oleh perilaku yang mencerminkan pilihan tindakan terhadap kegiatan-kegiatan yang dilakukan, 4) dari hasil belajar adalah informasi verbal, 5) keterampilan motorik.

Berdasarkan pernyataan di atas, dalam kontek penelitian ini dapat disimpulkan bahwa hasil belajar adalah hasil yang diperoleh siswa setelah mengalami interaksi dalam proses belajar mengajar atau proses pembelajaran. 
Hasil belajar siswa sangat ditentukan oleh banyak faktor. Menurut (Dimyati \& Mudjiono, 2002) hasil belajar yang dicapai siswa dipengaruhi dua faktor utama yaitu : a) Faktor intern (faktor dari diri siswa) seperti. (i) Itelegensi dan kemampauan yang dimiliki, (ii) kemapuan menggali hasil yang tersimpan, (iii) kemampuan berhasil atau unjuk hasil belajar, (iv) kemampuan mengolah bahan belajar, (v) kemampuan menyimpan perolehan hasil belajar, (vi) motivasi belajar dan kosentrasi belajar. Faktorfaktor inilah sangat mempengaruhi hasil belajar. b) Faktor eksteren ( faktor dari luar siswa) seperti: (i) guru sebagai pembina belajar, (ii) prasarana dan sarana pembelajaran, (iii) kebijakan penilaian, (iv) lingkungan sosial siswa di sekolah maupun di rumah, dan kurikulum sekolah.

Salah satu lingkungan belajar yang paling dominan mempengaruhi hasil belajar di sekolah adalah kualitas pengajaran yang dimaksud degan kualitas pengajaran adalah tinggi rendahnya atau efektif tidaknya proses belajar mengajar dalam mencapai tujuan pengajaran. Kedua faktor di atas yaitu kemampuan siswa dan kualitas pengajaran, mempunyai hubungan berbanding lurus dengan hasil belajar siswa. Artinya, makin tinggi kemampuan siswa dan kualitas pengajaran, makin tinggi pula hasil belajar siswa (Sudjana, 2001)

Dengan demikian, apabila guru dapat mendorong siswa agar senantiasa aktif dan proaktif dalam proses belajar mengajar maka siswa akan lebih bergairah serta termotivasi untuk belajar, siswa untuk mencapai kepuasan diri, dan kwalitas proses belajar dapat ditingkatkan. Oleh karena itu, dalam proses belajar mengajar guru hendaknya berpikir bagaimana menyajikan isi pelajaran supaya dapat mengaktifkan siswa.

\section{METODE PENELITIAN}

Penelitian ini adalah penelitian tindakan kelas (PTK), dengan tindakan berupa penerapan model pembelajaran Problem Based Learning (PBL) dengan pendekatan saintifik. Tempat pelaksanaan penelitian tindakan kelas ini adalah SMP Negeri 1 Dawan, yang beralamat di Jalan Sawo Kabeh Dawan Klod, Dawan Klungkung. Situasi sekolah ini sejuk dan rindang karena banyak pohon tumbuh di halaman sekolah, dan bersih karena di depan kelas disediakan tempat sampah. Rancangan yang digunakan dalam penelitian ini mengikuti model yang dibuat oleh Departemen Pendidikan. Siswa kelas IX A semester ganjil SMP Negeri 1 Dawan tahun pelajaran 2016/2017 adalah subjek dalam penelitian ini yang berjumlah 25 orang dimana 13 orang siswa perempuan dan 12 orang siswa laki-laki. Objek penelitian ini adalah peningkatan hasil belajar IPS siswa kelas IX A semester ganjil SMP Negeri 1 Dawan tahun pelajaran 2016/2017 melalui penerapan Problem Based Learning (PBL) dengan pendekatan saintifik pada saat proses belajar mengajar. Waktu penelitian ini dari bulan Juli sampai bulan Nopember tahun 2016. Tes prestasi belajar merupakan alat yang digunakan dalam mengumpulkan data hasil Penelitian Tindakan Kelas ini. Metode yang digunakan untuk menganalisis data hasil penelitian ini adalah metode deskriptif baik untuk data kualitatif maupun untuk data kuantitatif. Hasil yang diperoleh dari penelitian ini adalah data dalam bentuk angka, oleh karenanya analisis yang dilakukan adalah mencari mean, median, modus, membuat interval kelas dan 
melakukan penyajian dalam bentuk tabel dan grafik.

\section{HASIL PENELITIAN}

Perolehan data awal dapat dijelaskan : hanya 3 orang siswa $(12,00 \%)$ yang memperoleh nilai di atas KKM, 5 orang $(20,00 \%)$ yang memperoleh nilai sama dengan KKM dan 17 orang $(68,00 \%)$ yang memperoleh nilai di bawah KKM. Prosentase tersebut menunjukkan rendahnya prestasi siswa pada awalnya dalam menerpa ilmu pada mata pelajaran IPS. Gambaran dari data awal tersebut sudah barang tentu menuntut guru untuk bekerja lebih giat dan lebih keras dalam memperbaiki tingkat kemampuan mereka jika mau mengharapkan agar siswa mencapai prestasi sesuai dengan yang diharapkan.

Pada Siklus I dari 25 orang yang diteliti baru 9 orang $(36,00 \%)$ yang memperoleh nilai di atas KKM, 10 orang $(40,00 \%)$ yang memperoleh nilai sama dengan KKM dan 6 orang $(24,00 \%)$ yang memperoleh nilai di bawah KKM. Upaya yang dilakukan guru untuk mendorong kemampuan siswa sudah membuahkan hasil jika dibandingkan dengan data awal, yang menjadi landasan berpikir peneliti adalah segala sesuatu yang dipelajari membutuhkan waktu untuk mencapai tingkat yang diinginkan. Namun untuk lebih mempercepat tercapainya tujuan tersebut upaya memvariasikan media dan permainan tetap dilakukan agar motivasi dan minat anak tetap berkembang sesuai yang diharapkan.

Hasil yang diperoleh dari pelaksanaan penelitian di Siklus II ini adalah tingkat kemajuan yang dicapai siswa sudah menunjukkan perbaikan. Dari 25 orang yang diteliti, sudah 20 orang $(80,00 \%)$ yang memperoleh nilai di atas
KKM dan 5 orang $(20,00 \%)$ yang memperoleh nilai sama dengan KKM. Dengan dicapainya hasil seperti digambarkan di atas menyatakan indikator keberhasilan penelitian yang ditetapkan sudah dapat dicapai oleh semua siswa SMP Negeri 1 Dawan yakni sudah tidak ada lagi anak yang berada pada kategori tertinggal.

Tabel 1

Rekapitulasi Hasil Penelitian dari Awal sampai Siklus II

\begin{tabular}{|c|c|c|c|c|c|}
\hline \multirow[b]{2}{*}{$\begin{array}{c}\text { Variab } \\
\text { el }\end{array}$} & \multicolumn{3}{|c|}{ Awal Tes Siklus I } & \multicolumn{2}{|c|}{ Tes Siklus II } \\
\hline & $\begin{array}{c}\text { Peroleh } \\
\text { an } \\
\text { Nilai } \\
\text { Rata- } \\
\text { rata }\end{array}$ & $\begin{array}{c}\text { Peroleh } \\
\text { an } \\
\text { Nilai } \\
\text { Rata- } \\
\text { rata }\end{array}$ & $\begin{array}{l}\text { Prosent } \\
\text { ase } \\
\text { Kenaik } \\
\text { an }\end{array}$ & $\begin{array}{c}\text { Peroleha } \\
\text { n Nilai } \\
\text { Rata-rata }\end{array}$ & $\begin{array}{c}\text { Prosent } \\
\text { ase } \\
\text { Kenaik } \\
\text { an }\end{array}$ \\
\hline
\end{tabular}

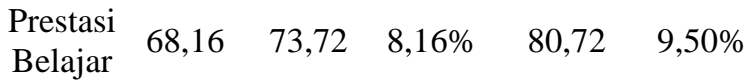

\section{SIMPULAN DAN SARAN}

Simpulan yang dapat disampaikan berdasar semua temuan hasil penelitian menunjukkan bahwa model pembelajaran problem based learning (PBL) yang telah dilaksanakan mampu menjawab rumusan masalah penelitian ini serta mampu membuktikan bahwa tujuan penelitian ini sudah dapat dicapai. Sebagai bukti atas pencapaian hal tersebut adalah: a) Pada kegiatan awal rata-rata kelas baru mencapai 68,16 dimana 3 orang $(12,00 \%)$ yang memperoleh nilai di atas KKM, 5 orang $(20,00 \%)$ yang memperoleh nilai sama dengan KKM dan 17 orang $(68,00 \%)$ yang memperoleh nilai di bawah KKM. b) Pada siklus I nilai rata-rata meningkat mencapai 73,72 dimana baru 9 orang $(36,00 \%)$ yang memperoleh nilai di atas KKM， 10 orang $(40,00 \%)$ yang memperoleh nilai sama dengan KKM dan 
6 orang $(24,00 \%)$ yang memperoleh nilai di bawah KKM. c) Pada siklus II nilai ratarata meningkat lagi mencapai 80,72 dimana sudah 20 orang $(80,00 \%)$ yang memperoleh nilai di atas KKM dan 5 orang $(20,00 \%)$ yang memperoleh nilai sama dengan KKM.

Hasil siklus ke II ternyata sudah melampui kreteria yang diusulkan sesuai indikator keberhasilan penelitian. Atas dasar perolehan data tersebut peneliti mengambil simpulan bahwa penerapan model pembelajaran problem based learning (PBL) mampu meningkatkan hasil belajar IPS siswa kelas IX A semester ganjil tahun pelajaran 2016/2017 di SMP Negeri 1 Dawan.

Saran-saran yang dapat disampaikan adalah: 1) Model yang digunakan dalam penelitian ini semestinya menjadi pilihan bagi guru-guru karena model ini telah terbukti dapat meningkatkan kerjasama, berkreasi, bertindak aktif, bertukar informasi, mengeluarkan pendapat, bertanya, berdiskusi, berargumentasi dan lain-lain. 2) Data hasil penelitian ini sudah mampu membuktikan peningkatan prestasi sesuai harapan. Namun peneliti adalah manusia biasa sehingga masuk banyak hal-hal yang belum sempurna dilakukan, oleh karenanya kepada peneliti lain agar meneliti bagian-bagian yang belum sempat diteliti. 3) Untuk memverifikasi hasil yang telah diperoleh disarankan pada bagi peneliti lain untuk melakukan penelitian lanjutan guna memverifikasi data hasil penelitian.

\section{DAFTAR PUSTAKA}

Depdiknas. (2003). Undang-Undang Republik Indonesia No 20 Tahun 2003 Tentang Sistem Pendidikan
Nasional. Jakarta.

Dimyati, \& Moerdjiono. (1994). Belajar dan Pembelajaran. Jakarta. PT

Rineka Cipta.

Dimyati, \& Mudjiono. (2002). Belajar dan Pembelajaran.

Gagne RM. (1988). Principles of Intructional Design. New York. Hol.Rinehart \&Wiston.

Poerwadarminta. (1996). Kamus Umum Bahasa Indonesia. Jakarta. Balai Pustaka, Jakarta.

Soeharto, K. (1984). Pengembangan Media Pembelajaran. Bandung. PT. Remaja Rosda Karya.

Sudiarta, W. (2005). Pengembangan dan Implementasi Pembelajaran Matematika berorientasi Pemecahan Masalah Konstekstual Open-Ended Untuk Siswa Sekolah Dasar di Propinsi Bali.

Sudjana, S. H. D. (2001). Metode \& teknik Pembelajaran Partisipatif. Bandung: Falah Production. 